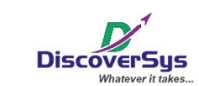

Published by DiscoverSys

\section{Factors related to Acceptance of HIV Testing by Pregnant Mothers in Health Centres in Denpasar City}

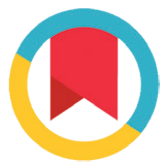

CrossMark

\author{
Ni Ketut Arniti, ${ }^{1,3^{*}}$ Luh Putu Wulandari, ${ }^{1,2}$ Dewa Nyoman Wirawan ${ }^{1,4}$
}

\section{ABSTRACT}

Purpose: To determine reasons of pregnant mothers to undergo HIV testing and factors influencing this decision.

Methods: The study design was a cross-sectional survey with a sample of 120 pregnant mothers seeking antenatal care in two sites: Puskesmas I Denpasar Utara and Puskesmas II Denpasar Selatan, during the period of 26 March to 22 April 2014. Data were collected through interviews using a structured questionnaire. Data were analysed using univariate to determine the frequency distribution of each variable, bivariate to determine the relationship between the dependent variable with each independent variable by the chi-squared test and multivariate analysis performed by logistic regression to determine the dominant factors to improve the acceptance of pregnant mothers to HIV testing.

Results: Reasons to undergo HIV testing were on recommendation from health providers $(65.8 \%)$, concern for personal status $(61.7 \%)$ and concerns about possibility of vertical transmission (19.2\%). Bivariate analysis showed that the acceptance by pregnant mothers was higher in mothers unemployed (75.8\%; $p=0.033)$, good knowledge about HIV and its transmission (78.4\%; $p=0.001$ ), was susceptible to HIV/AIDS (72.0\%; $\mathrm{p}=0.019)$, the perception that HIV/AIDS is a severe disease $(77.0 \%$; $p \leq 0.001)$, perceptions of the benefits of HIV testing $(70.8 \% ; p=0.002)$, absence perceived barriers (100\%; $p \leq 0.001)$ as well as good support from husband/family (87.7\%; $p \leq 0.001$ ). Multivariate analysis showed that factors influencing were support from husband/family with $\mathrm{OR}=8.71$ (95\%Cl: 2.89-26.28), perception of severity of HIV with OR=3.39 (95\%Cl: 1.08-10.69) and employment status with $\mathrm{OR}=2.82$ ( $95 \% \mathrm{Cl}: 1.07-7.42$ ). Conclusion: The majority of women to undergo HIV testing because of recommendations by staff and a desire to know HIV status. Acceptance of HIV testing among pregnant mothers was influenced by the support of the husband/family, the perception of the severity of HIV / AIDS, and employment status.

\title{
Faktor-faktor yang Berhubungan dengan Penerimaan Tes HIV oleh Ibu Hamil di Puskesmas Kota Denpasar
}

${ }^{1}$ Public Health Postgraduate Program, Udayana University, ${ }^{2}$ Department of Public Health, Faculty of Medicine Udayana University,

${ }^{3}$ Bali Province Health Department, ${ }^{4}$ Department of Community and Preventive Medicine, Faculty of Medicine Udayana University

*Correspondence to: Ni Ketut Arniti, Public Health Postgraduate Program, Udayana University, Bali Province Health Department

arniti_ketut@yahoo.co.id bahwa penerimaan oleh ibu hamil lebih tinggi pada ibu yang tidak bekerja $(75,8 \% ; p=0,033)$, pengetahuan baik tentang HIV dan penularannya $(78,4 \% ; p=0,001)$, merasa rentan terhadap HIV/ AIDS $(72,0 \% ; p=0,019)$, persepsi bahwa HIV/AIDS adalah penyakit yang parah (77,0\%; $p \leq 0,001)$, persepsi manfaat tes HIV $(70,8 \%$; $p=0,002)$, tidak adanya persepsi hambatan $(100 \% ; p \leq 0,001)$ serta dukungan yang baik dari suami/keluarga $(87,7 \% ; p \leq 0,001)$. Analisis multivariat menunjukkan bahwa faktor yang secara statistik signifikan meningkatkan penerimaan adalah dukungan suami/keluarga dengan $O R=8,71(95 \% \mathrm{Cl}: 2,89-26,28)$, persepsi keparahan penyakit dengan $O R=3,39(95 \% \mathrm{Cl}: 1,08-10,69)$ dan ibu hamil yang tidak bekerja dengan $\mathrm{OR}=2,82$ (95\% Cl: 1,07-7,42).

Simpulan: Kebanyakan ibu hamil menjalani tes HIV karena anjuran petugas dan ingin tahu status HIV. Penerimaan pada ibu hamil dipengaruhi oleh dukungan suami/keluarga, persepsi keparahan penyakit HIV/AIDS dan ibu hamil yang tidak bekerja. 
Kata kunci: penerimaan tes HIV, ibu hamil, Denpasar

Kutip artikel ini: Arniti, N.K., Wulandari, L.P., Wirawan, D.N. 2014. Faktor-faktor yang Berhubungan dengan Penerimaan Tes HIV oleh Ibu Hamil di Puskesmas Kota Denpasar. Public Health and Preventive Medicine Archive 2(1): 63-69. D0I:10.15562/phpma.v2i1.125

\section{PENDAHULUAN}

Human Immunodeficiency Virus/Acquired Immune Deficiency Syndrome (HIV/AIDS) merupakan masalah kesehatan di seluruh dunia termasuk Indonesia. ${ }^{1}$ Pada tahun 2000-an penularan HIV di Indonesia kebanyakan pada pemakai narkoba suntik dan sejak sekitar tahun 2008 mayoritas penularan HIV terjadi melalui hubungan heteroseksual berisiko yaitu dari wanita pekerja seks ke pelanggannya kemudian ke istri/pasangan seksualnya termasuk ibu hamil. ${ }^{2}$ Kementerian Kesehatan RI melaporkan pada tahun 2011, dari 21.103 ibu hamil yang menjalani tes HIV, sebanyak $534(2,5 \%)$ positif terinfeksi HIV. ${ }^{3}$ Menurut UNAIDS bila prevalensi HIV pada ibu hamil sama atau lebih dari $1 \%$ maka epedemi HIV di suatu negara/wilayah sudah termasuk epidemi yang generalized. ${ }^{4}$

Penularan HIV dari ibu hamil yang HIV positif ke bayi yang dikandungnya diperkirakan sebesar 20-50\%. ${ }^{5}$ Untuk mencegah penularan HIV dari ibu ke bayi sangat penting dilakukan tes HIV pada semua ibu hamil dan bila ditemukan positif segera dirujuk untuk pemberian ARV pada ibu maupun bayinya. ${ }^{6}$

Data WHO melaporkan bahwa cakupan ibu hamil yang sudah melakukan tes HIV pada tahun 2011 mengalami peningkatan, kecuali Indonesia yang masih tetap paling rendah yaitu $0,4 \%$ sedangkan negara lain di Asia seperti Vietnam dengan cakupan 39\%, China 75\%, Cambodia 78\% dan yang paling tinggi adalah Thailand yang telah mencapai 99\%.?

Untuk meningkatkan cakupan ibu hamil yang melakukan tes HIV dikaitkan dengan upaya pencegahan penularan HIV dari ibu ke anak di Indonesia, pada tahun 2012 pemerintah melalui Kementerian Kesehatan RI meluncurkan program Pencegahan Penularan HIV dari Ibu ke Anak (PPIA), yang mulai dilaksanakan di tempat pelayanan kesehatan milik pemerintah seperti rumah sakit dan puskesmas. ${ }^{8}$ Salah satu ruang lingkup PPIA adalah penawaran tes HIV oleh petugas kesehatan bagi semua ibu hamil yang mengakses layanan di fasilitas pelayanan kesehatan. ${ }^{8}$ Di Provinsi Bali program PPIA telah mulai dilaksanakan tahun 2013 di rumah sakit dan puskesmas termasuk Puskesmas I Denpasar Utara dan Puskesmas II Denpasar Selatan yang berada di wilayah Kota Denpasar.
Tes HIV pada semua ibu hamil dengan pendekatan Provider Initiative Testing and Councelling (PITC) merupakan strategi yang tepat untuk meningkatkan cakupan dan pencegahan penularan HIV dari ibu ke bayi, namun dari hasil penelitian sebelumnya yang dilaksanakan secara kualitatif menunjukkan bahwa tidak semua ibu hamil menerima tes HIV.,10 Sejauh ini, belum ada penelitian kuantitatif yang dilakukan untuk mengetahui faktor-faktor yang mempengaruhi penerimaan tes HIV oleh ibu hamil di Propinsi Bali. Dalam upaya untuk meningkatkan cakupan tes HIV pada ibu hamil maka sangat perlu diketahui faktor-faktor yang mempengaruhi penerimaannya. Berdasarkan hasil wawancara dengan delapan orang ibu hamil sebelum penelitian ini dimulai diperoleh bahwa beberapa alasan yang membuat ibu hamil tidak bersedia untuk menjalani tes HIV adalah karena merasa tidak bisa tertular, takut dengan hasil jika dilakukan tes, takut dengan pandangan negatif orang yang melihat ketika mengunjungi klinik Voluntary Councelling and Testing (VCT), khawatir terhadap pandangan masyarakat bila ketahuan positif HIV, ibu bekerja sehingga tidak ada waktu untuk melakukan tes HIV serta tidak mendapatkan ijin dari pasangan atau suami.

\section{METODE}

Penelitian ini merupakan penelitian survei cross sectional yang dilaksanakan pada ibu hamil pengunjung dua puskesmas di Kota Denpasar yaitu Puskesmas II Denpasar Selatan dan Puskesmas I Denpasar Utara. Sampel sebanyak 120 ibu hamil dan sekaligus sebagai responden dipilih secara concecutive dari semua ibu hamil yang melakukan ANC di puskesmas lokasi penelitian sejak tanggal 26 Maret 2014 sampai dengan 22 April 2014.

Variabel terikat dalam penelitian ini adalah penerimaan tes HIV oleh ibu hamil dan variabel bebasnya adalah umur, status pekerjaan, pendidikan, status perkawinan, jumlah kunjungan ANC, paritas, pengetahuan tentang HIV dan penularannya, persepsi kerentanan, keparahan, manfaat dan hambatan tes HIV, dukungan suami atau keluarga, dukungan petugas kesehatan serta dukungan teman.

Pengumpulan data dilakukan dengan wawancara menggunakan kuesioner terstruktur oleh peneliti sendiri dan empat orang bidan yang telah dilatih 
sebelumnya dan tidak bekerja di puskesmas lokasi penelitian. Analisis data dilakukan secara univariat untuk mengetahui distribusi responden menurut karakteristik. Analisis bivariat untuk melihat hubungan antara variabel terikat dengan masingmasing variabel bebas, dengan uji chi-square. Analisis multivariat dengan regresi logistik dilakukan untuk mengetahui hubungan antara keseluruhan variabel bebas dengan variabel terikat untuk mengetahui faktor yang meningkatkan penerimaan ibu hamil terhadap tes HIV.

Penelitian ini mendapatkan kelaikan etik dari Komisi Etik Penelitian Fakultas Kedokteran Universitas Udayana/Rumah Sakit Umum Pusat Sanglah Denpasar.

\section{HASIL}

Pada Tabel 1 dapat dilihat bahwa sebagian besar responden berumur $\geq 25$ tahun, tidak bekerja, sedang hamil kedua atau lebih, dan kunjungan ANC dua kali atau lebih. Dilihat dari pendidikan sebagian responden adalah tamat sekolah menengah atas atau lebih tinggi. Dari seluruh responden yang diwawancara semua dalam status kawin.

Pada Tabel 2 disajikan proporsi penerimaan tes HIV dan proporsi jawaban responden tentang pengetahuan, persepsi kerentanan, keparahan, manfaat dan hambatan tes HIV, dukungan suami atau keluarga, dukungan petugas kesehatan serta dukungan teman.

\section{Tabel 1 Karakteristik responden penelitian di puskesmas Kota} Denpasar

\begin{tabular}{lcc}
\hline Karakteristik & $\mathbf{n = 1 2 0}$ & $\%$ \\
\hline Umur & & \\
$\quad<25$ tahun & 40 & 33,3 \\
$\quad \geq 25$ tahun & 80 & 66,7 \\
Status pekerjaan & & \\
$\quad$ Tidak bekerja & 66 & 55,0 \\
$\quad$ Bekerja & 54 & 45,0 \\
Pendidikan & & \\
$\quad \geq$ Sekolah menengah atas & 60 & 50,0 \\
$\quad<$ Sekolah menengah atas & 60 & 50,0 \\
Status perkawinan & & \\
$\quad$ Kawin & 120 & 100 \\
Paritas & & \\
$\quad$ Multigravida & 78 & 65,0 \\
$\quad$ Primigravida & 42 & 35,0 \\
Jumlah kunjungan ANC & & \\
$\quad \geq 2$ & 107 & 89,2 \\
$\quad<2$ & 13 & 10,8 \\
\hline
\end{tabular}

Sebanyak 65,8\% responden mengungkapkan bahwa mereka melakukan tes HIV dengan alasan mengikuti anjuran petugas kesehatan, 61,7\% mengatakan oleh karena ingin tahu ststus HIV, $19,2 \%$ oleh karena untuk melindungi anak, 2,5\% untuk melindungi pasangan dan $1,7 \%$ karena merasa memiliki risiko tertular HIV. Alasan tidak menerima tes adalah $23,3 \%$ karena takut diambil darah, $18,3 \%$ takut mengetahui hasil tes, $16,7 \%$ tidak mendapat ijin suami.

Hasil analisis bivariat seperti disajikan pada Tabel 3 menunjukkan bahwa variabel yang secara bermakna berhubungan dengan penerimaan tes HIV oleh ibu hamil yaitu status ibu hamil yang tidak bekerja, pengetahuan tentang HIV dan penularannya, persepsi kerentanan terhadap HIV/ AIDS, persepsi keparahan penyakit HIV/AIDS, manfaat tes HIV, persepsi hambatan tes HIV serta dukungan suami atau keluarga. Pada kelompok responden yang bekerja cenderung lebih sedikit yang menerima tes HIV yaitu sebanyak 57,4\% sedangkan pada kelompok yang tidak bekerja sebanyak $75,8 \%(\mathrm{p}=0,033)$. Pada responden yang berpengetahuan HIV/AIDS baik sebanyak 78,4\% menerima tes dan yang berpengetahuan kurang sebanyak $50,0 \%(\mathrm{p}=0,001)$. Mereka yang merasa rentan terhadap HIV/AIDS, 72,0\% menerima tes dan yang merasa tidak rentan $45,0 \%(\mathrm{p}=0,019)$. Responden yang memiliki persepsi bahwa HIV/ AIDS adalah penyakit yang parah sebesar 77,0\% menerima tes dan yang menyatakan tidak parah $42,4 \% \quad(p<0,001)$. Sebanyak $70,8 \%$ responden mempunyai persepsi bahwa tes HIV bermanfaat dan menerima tes, sedangkan $14,3 \%$ menyatakan tidak bermanfaat $(p<0,002)$. Semua responden yang menerima tes HIV tidak memiliki persepsi hambatan untuk tes $(\mathrm{p}<0,001)$. Responden dengan dukungan suami atau keluarga yang baik sebesar $87,7 \%$ menerima tes dan dukungan suami atau keluarga kurang baik 49,2\% ( $\mathrm{p}<0,001)$.

Hasil analisis multivariat seperti disajikan pada Tabel 4 terlihat bahwa variabel yang meningkatkan penerimaan tes HIV pada ibu hamil adalah status pekerjaan, persepsi keparahan terhadap HIV/AIDS dan dukungan suami atau keluarga. Ibu yang tidak bekerja 2,82 kali lebih mungkin menerima tes HIV dibandingkan dengan ibu yang bekerja (95\%CI: 1,07-7,42). Ibu yang memiliki persepsi keparahan yang tinggi 3,39 kali lebih mungkin untuk menerima tes HIV daripada ibu yang memiliki persepsi keparahan yang rendah tentang HIV/AIDS (95\%CI: 1,08-10,69). Ibu yang memiliki dukungan baik dari suami atau keluarga 8,71 kali lebih mungkin untuk menerima tes HIV dibandingkan dengan ibu yang memiliki dukungan kurang dari suami atau keluarga $(95 \% \mathrm{CI}=2,89-26,28)$. 
Tabel 2 Penerimaan tes HIV, pengetahuan, persepsi dan dukungan

\begin{tabular}{|c|c|c|}
\hline Variabel & $n=120$ & $\%$ \\
\hline \multicolumn{3}{|l|}{ Penerimaan tes HIV } \\
\hline Ya & 81 & 67,5 \\
\hline Tidak & 39 & 32,5 \\
\hline \multicolumn{3}{|c|}{ Pengetahuan tentang HIV dan penularannya } \\
\hline Baik & 74 & 61,7 \\
\hline Kurang & 46 & 38,3 \\
\hline \multicolumn{3}{|l|}{ Persepsi kerentanan terhadap HIV } \\
\hline Merasa rentan & 100 & 83,3 \\
\hline Tidak merasa rentan & 20 & 16,7 \\
\hline \multicolumn{3}{|l|}{ Persepsi keparahan HIV/AIDS } \\
\hline HIV penyakit yang parah & 87 & 72,5 \\
\hline HIV penyakit yang tidak parah & 33 & 27,5 \\
\hline \multicolumn{3}{|l|}{ Persepsi manfaat tes HIV } \\
\hline Bermanfaat & 113 & 94,2 \\
\hline Tidak bermanfaat & 7 & 5,8 \\
\hline \multicolumn{3}{|l|}{ Persepsi hambatan tes HIV } \\
\hline Ada hambatan & 39 & 32,5 \\
\hline Tidak ada hambatan & 81 & 67,5 \\
\hline \multicolumn{3}{|l|}{ Dukungan suami atau keluarga } \\
\hline Baik & 57 & 47,5 \\
\hline Kurang & 63 & 52,5 \\
\hline \multicolumn{3}{|l|}{ Dukungan petugas kesehatan } \\
\hline Baik & 109 & 90,8 \\
\hline Kurang & 11 & 9,2 \\
\hline \multicolumn{3}{|l|}{ Dukungan teman } \\
\hline Ada & 13 & 10,8 \\
\hline Tidak ada & 107 & 89,2 \\
\hline
\end{tabular}

Tabel 3 Penerimaan tes HIV oleh ibu hamil berdasarkan karakteristik responden, pengetahuan, persepsi dan dukungan

\begin{tabular}{|c|c|c|c|}
\hline \multirow[b]{2}{*}{ Variabel } & \multicolumn{2}{|c|}{ Penerimaan tes HIV } & \multirow[b]{2}{*}{ Nilai $p^{*}$} \\
\hline & $\begin{array}{c}\text { Ya } \\
\text { n (\%) }\end{array}$ & $\begin{array}{l}\text { Tidak } \\
\text { n (\%) }\end{array}$ & \\
\hline \multicolumn{4}{|l|}{ Umur } \\
\hline$<25$ tahun & $30(75,0)$ & $10(25,0)$ & 0,215 \\
\hline$\geq 25$ tahun & $51(63,8)$ & $29(36,3)$ & \\
\hline \multicolumn{4}{|l|}{ Status pekerjaan } \\
\hline Tidak bekerja & $50(75,8)$ & $16(24,2)$ & 0,033 \\
\hline Bekerja & $31(57,4)$ & $23(42,6)$ & \\
\hline \multicolumn{4}{|l|}{ Pendidikan } \\
\hline$\geq$ Sekolah menengah atas & $41(68,3)$ & $19(31,7)$ & 0,845 \\
\hline$<$ Sekolah menengah atas & $40(66,7)$ & $20(33,3)$ & \\
\hline \multicolumn{4}{|l|}{ Paritas } \\
\hline Multigravida & $52(66,7)$ & $26(33,3)$ & 0,791 \\
\hline Primigravida & $29(69,0)$ & $13(31,0)$ & \\
\hline
\end{tabular}




\begin{tabular}{|c|c|c|c|}
\hline \multirow[b]{2}{*}{ Variabel } & \multicolumn{2}{|c|}{ Penerimaan tes HIV } & \multirow[b]{2}{*}{ Nilai $\mathbf{p}^{*}$} \\
\hline & $\begin{array}{c}\text { Ya } \\
\text { n (\%) }\end{array}$ & $\begin{array}{l}\text { Tidak } \\
\text { n (\%) }\end{array}$ & \\
\hline \multicolumn{4}{|l|}{ Kunjungan ANC } \\
\hline$\geq 2$ & $74(69,2)$ & $33(30,8)$ & 0,266 \\
\hline$<2$ & $7(53,8)$ & $6(42,6)$ & \\
\hline \multicolumn{4}{|c|}{ Pengetahuan tentang HIV dan penularannya } \\
\hline Baik & $58(78,4)$ & $16(21,6)$ & 0,001 \\
\hline Kurang & $23(50,0)$ & $23(50,0)$ & \\
\hline \multicolumn{4}{|l|}{ Persepsi kerentanan HIV/AIDS } \\
\hline Merasa rentan & $72(72,0)$ & $28(28,0)$ & 0,019 \\
\hline Tidak merasa rentan & $9(45,0)$ & $11(55,0)$ & \\
\hline \multicolumn{4}{|l|}{ Persepsi keparahan HIV/AIDS } \\
\hline HIV penyakit yang parah & $67(77,0)$ & $20(23,0)$ & $<0,001$ \\
\hline HIV penyakit yang tidak parah & $14(42,4)$ & $19(57,6)$ & \\
\hline \multicolumn{4}{|l|}{ Persepsi manfaat tes HIV } \\
\hline Bermanfaat & $80(70,8)$ & $33(29,2)$ & 0,002 \\
\hline Tidak bermanfaat & $1(14,3)$ & $6(85,7)$ & \\
\hline \multicolumn{4}{|l|}{ Persepsi hambatan tes HIV } \\
\hline Ada hambatan & $0(0,0)$ & $39(100)$ & $<0,001$ \\
\hline Tidak ada hambatan & $81(100)$ & $0(0,0)$ & \\
\hline \multicolumn{4}{|l|}{ Dukungan suami atau keluarga } \\
\hline Baik & $50(87,7)$ & $7(12,3)$ & $<0,001$ \\
\hline Kurang & $31(49,2)$ & $32(50,8)$ & \\
\hline \multicolumn{4}{|l|}{ Dukungan petugas kesehatan } \\
\hline Baik & $74(67,9)$ & $35(32,1)$ & 0,774 \\
\hline Kurang & $7(63,6)$ & $4(36,4)$ & \\
\hline \multicolumn{4}{|l|}{ Dukungan teman } \\
\hline Baik & $8(61,5)$ & $5(38,5)$ & 0,627 \\
\hline Kurang & $73(68,2)$ & $34(31,8)$ & \\
\hline
\end{tabular}

${ }^{\star} X^{2}$ Test

Tabel 4 Adjusted OR variabel bebas dengan penerimaan tes HIV pada ibu hamil

\begin{tabular}{lccc}
\hline Variabel & Adjusted OR & $\mathbf{9 5 \%} \mathbf{C l}$ & Nilai p \\
\hline Status pekerjaan & 2,82 & $1,07-7,42$ & 0,036 \\
Pengetahuan & 1,61 & $0,50-5,13$ & 0,417 \\
Persepsi kerentanan & 1,57 & $0,40-6,12$ & 0,512 \\
Persepsi keparahan HIV/AIDS & 3,39 & $1,08-10,69$ & 0,037 \\
Persepsi manfaat tes HIV & 4,90 & $0,48-50,94$ & 0,183 \\
Dukungan suami atau keluarga & 8,71 & $2,89-26,28$ & $<0,001$ \\
\hline
\end{tabular}

\section{DISKUSI}

Dalam penelitian ini ditemukan tiga faktor yang secara bermakna berhubungan dengan penerimaan tes HIV yaitu dukungan suami atau keluarga, status pekerjaan dan persepsi keparahan penyakit HIV/
AIDS. Ibu hamil yang memiliki dukungan baik dari suami atau keluarga 8,71 kali lebih mungkin untuk menerima tes HIV dibandingkan dengan ibu yang memiliki dukungan kurang dari suami 
atau keluarga $(\mathrm{OR}=8,71 ; \quad 95 \% \mathrm{CI}=2,89-26,28)$. Temuan ini sejalan dengan yang dikemukakan oleh Green (1980) dalam Notoatmodjo (2007) bahwa reinforcing factors (dalam hal ini dukungan suami atau keluarga) merupakan salah satu faktor untuk terbentuknya suatu perilaku. ${ }^{11}$ Pada Buku Panduan PPIA, juga dicantumkan bahwa pentingnya dukungan suami untuk menunjang keberhasilan pencegahan penularan HIV dari ibu ke anak. ${ }^{9}$ Hasil penelitian ini sejalan dengan penelitian sebelumnya di Indonesia yaitu penelitian di Singaraja, Bali oleh Aryasih (2012) dan penelitian di Semarang oleh Legiati dkk. (2012). ${ }^{10,12}$ Penelitian sejenis di luar negeri yang menunjukkan hasil yang sama yaitu penelitian oleh De Paoli dkk. (2004) di Tanzania, penelitian oleh Ambaye (2006) dan Worku (2005) di Ethiophia. ${ }^{13-15}$ Penelitian di Singaraja, Bali oleh Aryasih (2012) menemukan bahwa alasan ibu hamil tidak melakukan tes HIV adalah dikarenakan kuatnya budaya patriarki yang mempengaruhi penerimaan ibu hamil terhadap tes HIV. ${ }^{10} \mathrm{Hal}$ ini menunjukkan bahwa dukungan suami terhadap ibu sangat berpengaruh terhadap perilaku ibu untuk menerima tes HIV. Temuan penelitian ini sejalan dengan penelitian kuantitatif yang dilakukan di Semarang oleh Legiati dkk. (2012) bahwa 51,1\% ibu hamil menerima tes HIV karena dukungan suami dan dilaporkan sebesar 15,7 kali lebih mungkin untuk menerima tes HIV pada ibu hamil yang mendapat dukungan baik dari suami dibandingkan yang memiliki dukungan suami kurang. ${ }^{12}$ Penelitian yang dilakukan oleh De Paoli dkk. (2004) di Tanzania juga menunjukkan hasil yang sama bahwa dukungan dari pasangan dan atau anggota keluarga menjadi faktor penting dalam menentukan apakah seorang wanita mampu sepenuhnya berpartisipasi dalam tes HIV untuk mencegah penularan HIV dari ibu ke bayi. ${ }^{13}$ Penelitian yang dilaksanakan di Ethiophia oleh Ambaye (2006) menemukan hasil serupa bahwa peran pasangan untuk pengambilan keputusan dan reaksi pasangan terhadap hasil tes yang positif mempengaruhi ibu untuk menerima tes HIV. ${ }^{14}$ Penelitian serupa dengan rancangan gabungan kuantitatif dan kualitatif di Gambella Ethiopia oleh Worku (2005) menemukan bahwa ibu hamil menyatakan perceraian sebagai respon yang diberikan oleh suami mereka setelah hasil tes yang diterima ibu adalah HIV positif dan ketika ibu tidak mengungkapkan dan mencari persetujuan dari suami mereka untuk tes $\mathrm{HIV}^{15}$ Kondisi ini menunjukkan bahwa dukungan suami atau keluarga terhadap penerimaan tes HIV oleh ibu hamil adalah sangat penting.

Hasil penelitian ini menunjukkan bahwa ibu yang tidak bekerja proporsi untuk melakukan tes HIV lebih besar $(75,8 \%)$ daripada ibu hamil yang bekerja (57,4\%). Bekerja atau tidaknya ibu berhubungan secara signifikan dengan penerimaan tes HIV oleh ibu hamil. Ibu hamil yang tidak bekerja 2,82 kali lebih mungkin menerima tes HIV dibandingkan dengan ibu yang bekerja $(95 \% \mathrm{CI}$ : 1,07-7,42). Dalam beberapa penelitian lain ditemukan bahwa pekerjaan berhubungan dengan penerimaan tes HIV dan ada pula yang menemukan pekerjaan tidak berhubungan dengan penerimaan tes HIV. Hasil penelitian ini sejalan dengan hasil penelitian oleh Moges dan Amberbir (2011) yang menemukan bahwa pekerjaan berhubungan secara signifikan dengan penerimaan tes HIV oleh ibu hamil. Hal ini disebabkan karena ibu yang bekerja lebih banyak terpapar oleh informasi tentang HIV/AIDS. ${ }^{16}$ Berbeda dengan hasil penelitian di Semarang oleh Legiati dkk. (2012) menemukan bahwa tidak adanya hubungan penerimaan tes HIV oleh ibu hamil dengan pekerjaan. ${ }^{12}$ Penelitian oleh Kwofie (2008) juga menemukan bahwa pekerjaan tidak berhubungan dengan penerimaan tes HIV oleh ibu hamil dengan $\mathrm{OR}=0,83 \quad(95 \% \mathrm{CI}=0,41$ 1,68). ${ }^{17}$ Penerimaan tes HIV pada ibu yang tidak bekerja dalam penelitian ini kemungkinan berkaitan dengan proses pelayanan tes HIV di puskesmas. Salah satu puskesmas tempat penelitian menerapkan prosedur tes dengan cara pemberian informasi kepada ibu kemudian penawaran tes HIV di klinik antenatal dan apabila ibu bersedia untuk tes HIV maka ibu dirujuk ke klinik VCT untuk mendapat konseling pra tes. Setelah konseling pra tes ibu melanjutkan pemeriksaan darah di laboratorium yang kemudian membuka hasil di klinik VCT yang dilanjutkan dengan konseling pasca tes dan setelah mengetahui status HIV-nya ibu kembali ke klinik antenatal. Proses ini memerlukan waktu yang cukup lama sehingga ada kemungkinan ibu hamil memutuskan untuk mengambil hasil tes di hari yang berbeda atau tidak bersedia tes karena waktu yang dimiliki sangat terbatas. Waktu yang terbatas yang dimiliki ibu terutama ibu yang bekerja membuat ibu menjadi enggan untuk tes HIV.

Dari penelitian ini diperolah bahwa proporsi ibu hamil yang memiliki persepsi keparahan penyakit HIV/AIDS tinggi, proporsi yang menerima tes HIV $(77,0 \%)$ lebih besar daripada persepsi keparahan rendah $(42,4 \%)$, dan dijumpai hubungan yang signifikan antara persepsi keparahan dengan penerimaan tes HIV oleh ibu hamil. Ibu hamil yang memiliki persepsi keparahan yang tinggi 3,39 kali lebih mungkin untuk menerima tes HIV daripada ibu yang memiliki persepsi keparahan yang rendah tentang HIV/AIDS (95\%CI: 1,08-10,69). Temuan ini sesuai dengan teori Health Belief Model oleh Rosenstock (1974) dalam Glanz dkk. (1991) bahwa 
seseorang akan melakukan tindakan pengobatan atau pencegahan bila merasa terancam oleh penyakit yang dirasakan lebih parah dibandingkan dengan penyakit yang dirasakan lebih ringan. Begitu pula persepsi keparahan yang tinggi tentang penyakit HIV/AIDS akan membuat seseorang mengambil tindakan pencegahan atau deteksi dini terhadap penyakit tersebut. ${ }^{18}$ Penelitian oleh Legiati dkk. (2012) di Semarang dan penelitian oleh Moges dan Amberbir (2011) di Ethiophia menemukan hasil yang berbeda dari penelitian ini dan berbeda pula dengan teori Health Belief Model. Kedua penelitian tersebut menemukan bahwa persepsi keparahan tidak berhubungan dengan perilaku tes HIV pada ibu hamil. ${ }^{12,16}$

Keterbatasan penelitian adalah informasi yang diperoleh kurang mendalam karena penelitian ini merupakan penelitian survei dan diperlukan penelitian lanjut yang lebih mendalam.

\section{SIMPULAN}

Alasan ibu hamil untuk menerima tes HIV sebagian besar karena mengikuti anjuran petugas kesehatan dan ingin tahu status HIV. Hanya sebagian kecil dengan alasan untuk melindungi bayi yang dikandung yang sesungguhnya merupakan tujuan tes HIV selama kehamilan. Alasan tidak menerima tes HIV adalah karena takut diambil darah, takut hasil tes yang akan diterima, tidak mendapat ijin dari suami dan alasan waktu yang tidak sesuai dengan jam kerjanya. Faktor yang ditemukan berpengaruh terhadap penerimaan tes HIV oleh ibu hamil adalah dukungan suami atau keluarga, persepsi keparahan penyakit HIV/AIDS dan status ibu hamil yang tidak bekerja.

\section{UCAPAN TERIMA KASIH}

Ucapan terima kasih penulis sampaikan kepada Kepala Puskesmas I Denpasar Utara dan Kepala Puskesmas II Denpasar Selatan dan semua pihak yang telah membantu pelaksanaan penelitian ini.

\section{DAFTAR PUSTAKA}

1. Departemen Kesehatan RI, Pusat Data dan Informasi. Situasi HIV/AIDS di Indonesia Tahun 1987-2006. Jakarta; 2006.

2. Komisi Penanggulangan AIDS Nasional. Rencana Aksi nasional Penanggulangan HIV/AIDS di Indonesia Tahun 2007-2010. Jakarta; KPAN; 2007.
3. Kementerian Kesehatan RI, Subdirektorat AIDS dan PMS. Laporan Triwulan IV 2011 Kasus HIV-AIDS Nasional. Jakarta; 2011.

4. United Nations Programme on HIV/AIDS. Terminology Guidelines. UNAIDS; 2011.

5. De Cock KM, Foweler MG, Maercier. Prevention of Mother to Child HIV Transmission in Resource Countries: Translating Research into Policy and Practice. JAMA; 2000.

6. World Health Organization. PMTCT Strategic Vision 2010-2015 Preventing Mother to Child Transmission of HIV Reach the UNGASS and Millennium Development Goal. Switzland; 2010.

7. Srikantiah P, Lo Y, Baggaley R, Pandse R, Shaffer N. Antenatal HIV Testing and Counselling Practices in Seven Asian Countries: Working Towards Elimination of eMTCT in Low and Concentrated Epidemic Settings. Kuala Lumpur; 2013.

8. Kementerian Kesehatan RI. Surat Edaran Menteri Kesehatan Nomor GK/MENKES/001/2013 Tentang layanan Pencegahan penularan Human Immunodeficiency Virus (HIV) dari Ibu ke Anak (PPIA). Jakarta; 2013.

9. Kementerian Kesehatan RI. Pedoman Nasional Pencegahan Penularan HIV dari Ibu ke Anak (PPIA). Jakarta; 2012.

10. Aryasih P.T. Peran Hambatan dan Tantangan Bidan di Layanan Antenatal Care (ANC) untuk Merujuk Ibu Hamil dalam Penemuan Kasus HIV di Kecamatan Serisit Kabupaten Buleleng Tahun 2011. Denpasar; Universitas Udayana; 2012.

11. Notoatmodjo S. Promosi Kesehatan dan Ilmu Perilaku. Jakarta: Rineka Cipta; 2007.

12. Legiati Titi PS, Shaluhiyah Z, Suryoputro A. Perilaku Ibu Hamil untuk Tes HIV di Kelurahan Bandarharjo dan Tanjung Mas Kota Semarang. Jurnal Promosi Kesehatan Indonesia. $2010 \mathrm{Vol}, 7 / \mathrm{No} .2 /$ Agustus 2012.

13. De Paoli MM, Manongi R, Klepp KI. Factors Influencing Acceptability of Voluntary Counselling and HIV Tersting among Pregnant Women in Northern Tanzania. AIDS Care 2004. Available from: http://www.ncbi.nlm.nih.gov/ pubmed/1520 3410.

14. Ambaye B.Y. Willingness of Pregnant Women Attending Antenatal Care toward Voluntary Counseling and Testing. 2006 (thesis) Addis Ababa University; 2006.

15. Worku G. Factors Determining Acceptance of Vouluntary HIV Testing among Pregnant Women Attending Antenatal Clinic at Armed Force Hospital in Addis Ababa. (thesis) Addis Ababa University; 2005.

16. Moges Z, Amberbir A. Factors Associated with Readiness to VCT Service Utilization among Pregnant Women Attending Antenatal Clinics in Northwestern Ethiopia: A Health Belief Model Approach. Ethiopian Journal of Health Scinces; 2011.

17. Kwofie GS. Acceptance of HIV Counselling and Testing Among Pregnant Women in the Kumasi Metropolis. Kumasi: Kwame Nkrumah University of Scince and Technology; 2008.

18. Glanz K, Lewis FM, Rimer BK. Health Behavior and Health Education: Theory Research and Practice. San Francisco: Jossey-Bass Publishers;1991.

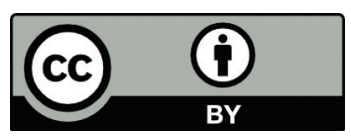

This work is licensed under a Creative Commons Attribution 